\title{
A potência da recusa - algumas lições ameríndias
}
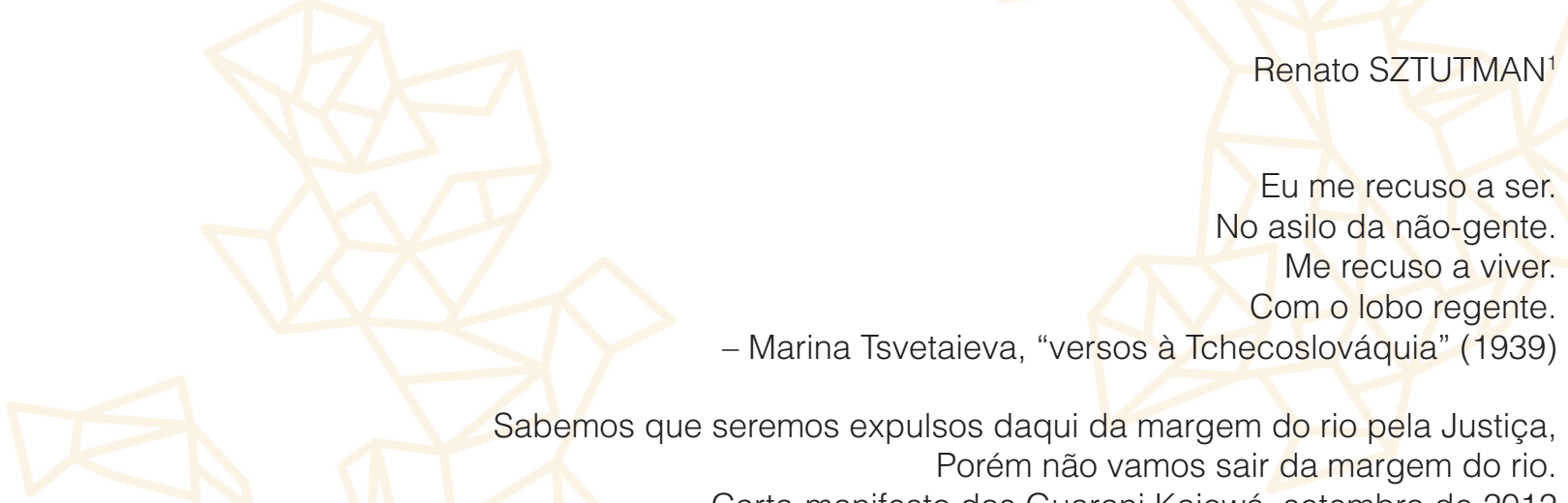

\section{Resumo}

Visando discorrer sobre temas presentes no espetáculo Recusa, este ensaio faz com que certos acontecimentos históricos encontrem-se com as reflexões de Pierre Clastres, autor de $A$ sociedade contra o Estado, sobre a recusa ameríndia do poder político coercitivo e sua escolha pela liberdade. Parte, em seguida, para algumas considerações sobre a leitura dessas ideias por Gilles Deleuze e Félix Guattari, que propõem estender o sentido da recusa indígena para o "nosso" mundo (ocidental, moderno, capitalista), vislumbrando possibilidades de criação e resistência. Reencontra, por fim, o tema ameríndio nos escritos de Clastres sobre a metafísica dos índios Guarani e nas reflexões de LéviStrauss sobre o "dualismo em perpétuo desequilíbrio" como antídoto da identidade.

Palavras-chave: recusa; dualismo; povos ameríndios; criação

Recusa, o espetáculo, estreou em outubro de 2012 num momento delicado para os povos indígenas. Na mesma época, um coletivo de índios Guarani Kaiowá, da comunidade Pyelito Kue e Mbarakay (Mato Grosso do Sul), divulgava uma carta-manifesto, protestando contra a ineficácia da justiça federal em lhes assegurar o direito à ocupação de seu território tradicional às margens do rio Hovy, ineficácia que acaba por corroborar com uma ação genocida levada a cabo há décadas por agentes do agronegócio e seus aliados. A carta-protesto terminava com um atestado de desalento:

Sabemos que não temos mais chance em sobreviver dignamente aqui em nosso território antigo, já sofremos muito e estamos todos massacrados e morrendo em ritmo acelerado. Sabemos que seremos expulsos daqui da margem do rio pela Justiça, porém não vamos sair da margem do rio. Como um povo nativo e indígena histórico, decidimos meramente em sermos

\footnotetext{
1 Renato Sztutman é professor do Departamento de Antropologia da Universidade de São Paulo e autor do livro O profeta e o principal (Edusp/FAPESP, 2012)
} 
mortos coletivamente aqui. Não temos outra opção. Esta é a nossa última decisão unânime diante do despacho da Justiça Federal de Navirai-MS.

Esse desalento chocou o Brasil, disparando uma campanha nas redes sociais, não livre de antagonistas engajados com preconceitos e interesses anti-indígenas. Refletia, contudo, não a ameaça de um suicídio coletivo, como foi interpretada por muitos, mas a recusa existencial de viver num mundo em que não há lugar para outros mundos que não aqueles baseados no desenvolvimento econômico e no poder do capital, a recusa de viver num mundo sem liberdade, sob ameaça contínua de violência física e moral. ${ }^{2}$ Recusa ativa que indica o não conformismo e a iminência da luta. Os povos Guarani, espalhados na imensidão da bacia do Prata e suas cercanias, têm resistido mais de 500 anos ao avanço do "nosso" mundo - ocidental, moderno, capitalista. ${ }^{3}$ Viveram ao "nosso" lado - na periferia de nossas cidades, nas beiras das estradas, nos litorais - de maneira quase imperceptível, sem abrir mão de suas escolhas éticas que dizem respeito às relações humanas e às relações com o ambiente, bem como de sua predileção pela mobilidade, pela livre circulação em um espaço aberto, que hoje Ihes é privado. Depois de tantos anos de expropriação e extermínio, parecem ter se tornado finalmente mais visíveis para "nós" que, aos poucos, tentamos compreender suas recusas.

Na semana em que assisti pela primeira vez a Recusa, a bilheteria estava destinada ao povo Guarani Kaiowá. E, terminado o espetáculo, os dois atores não se furtaram a alertar o público sobre a campanha que estava se desenhando. Sensibilidade e compromisso em relação à recusa dos Guarani Kaiowá e de outros tantos povos indígenas, que os brasileiros tão pouco conhecem, é algo que bem poderia definir o espetáculo Recusa. Não por acaso, este se inspirou em uma notícia de jornal de 1998, que falava de outro massacre e de outra recusa, a de um povo - os Piri-

\footnotetext{
2 Spensy Pimentel, estudioso e engajado na luta dos Kaiowá, reconhece nessa leitura do "suicídio coletivo" os ecos da epidemia de suicídios que tem acometido jovens kaiowá em diferentes partes. Segundo ele, isso se deve ao confinamento excessivo desses grupo. Busca-se reverter esse quadro a partir do crescimento dos movimentos articulados para a recuperação das terras. Nesse sentido, escreve Pimentel (2012), "acampamentos como o de Pyelito não são signos de desesperança e sim de esperança, são uma reação dos indígenas à indiferença e à morosidade dos brancos no que se refere a devolver-lhes o que lhes foi tomado - apesar de, no papel, com a Constituição de 1988, o país ter assumido um compromisso público de regularizar as terras indígenas". Para acessar a carta-manifesto dos Kaiowá, ver link: (http://desinformemonos.org/2012/10/decretemnossa-morte-coletiva-e-nos-enterrem-todos-aqui-dizem-guarani-kaiowa-da-comunidade-de-pyeblito-kue/)

3 Os Guarani compreendem três subgrupos: Mbyá, Chiripá e Kaiowá. Espalham-se para além da bacia do Prata, podendo ser encontrados em regiões as mais diversas da América do Sul, como o piemonte andino da Bolívia e o sul do estado do Pará.
} 
pkura - que, diferentemente dos povos Guarani, escolheram não manter contato continuado com a sociedade brasileira. ${ }^{4} \mathrm{~A}$ notícia falava de dois indivíduos, que sobreviveram ao massacre de seu povo e que, após certo tempo fugindo dos mal tratos dos brancos, acabaram por buscar contato. Um deles, Tucan, encontrava-se muito doente, sendo submetido a tratamento médico na cidade de Jiparaná, estado de Rondônia. O outro, Mande'í, manteve distância. Quando Tucan terminou o tratamento, encontrou seu irmão e, juntos, desapareceram novamente na mata. Recusaram o contato, como muitos outros povos que permanecem "isolados" na Amazônia. Em 2013, os Piripkura - não se sabe ao certo qual o número dos sobreviventes - ainda aguardam pela demarcação de suas terras, permanecendo vulneráveis a ações de fazendeiros e madeireiros. Enquanto isso, continuam recusando o contato com a Funai e mesmo com outros povos, como os Gavião, de quem, aliás, vem o nome piripkura, que na língua desses inimigos significa "borboleta", modo pejorativo de se referir a este povo que está sempre se escondendo e perambulando pela floresta.

A situação dos Piripkura poderia ser aproximada à de muitos outros povos. Por exemplo, à dos Mashco Piro, da Amazônia peruana, situação que o antropólogo britânico Peter Gow (2011) designou como "isolamento voluntário" - ação intencional, baseada na recusa de qualquer relação social com o "mundo dos brancos", no qual muitas vezes estão inseridos outros povos indígenas. Mas o "isolamento voluntário" é apenas uma das formas, e talvez uma forma extremada dada a iminência de tamanha violência, de uma recusa ativa, que se manifesta, por exemplo, nas reivindicações dos diferentes povos que se aglutinam nos canteiros da hidrelétrica de Belo Monte (sudeste do Pará) ou no profundo desalento dos Guarani Kaiowá, que declararam desistir da vida nesse mundo.

A ideia de uma recusa ativa foi, aliás, o grande tema perseguido pelo antropólogo francês Pierre Clastres, ao longo das décadas de 1960 e 1970, quando as forças do capital avançavam de modo gritante sobre as florestas sul-americanas, ameaçando a sobrevivência física e moral das mais diversas populações indígenas. Mas Clastres não falava simplesmente na reação dos índios ao "contato" com os brancos, falava sim de uma resistência primeira, uma resistência a todo poder de unificação, de subordinação e de coerção. Eis o sentido da "sociedade contra o Estado", assunto sobre o qual gostaria de falar nas próximas páginas, extraindo algumas de suas consequências.

4 Os Piripkura são um povo de língua tupi-kawahib - tupi-guarani como os Guarani - que costumava circular na região de fronteira dos estados de Mato Grosso e Rondônia. 
Clastres afirma que as sociedades indígenas são "sociedades contra o Estado". Isso não significa que elas são sociedades "sem" Estado - leitura que faria o argumento do autor recair tanto no evolucionismo (a "simplicidade" de tais organizações), quanto no romantismo (os índios desconhecem toda forma de poder). Isso significa que elas recusam não exatamente o Estado, tal como o conhecemos em suas formas modernas, um Estado inventado na era moderna, mas sim a possibilidade de um poder unificado e unificante, capaz de subordinação e de coerção (ação violenta). Recusa-se aquilo que se (re)conhece; recusa-se aquilo que se pode ser, ou vir a ser. Recusa-se, por exemplo, um pacto fáustico, a promessa de um mundo desenvolvido e em crescimento, que tem como preço o sacrifício de certas relações, tanto as relações interpessoais como aquelas estabelecidas com o mundo natural. Em suma, as sociedades indígenas seriam, para Clastres, "contra o Estado" na medida em que evitam a formação de um poder separado e transcendente em relação ao tecido das relações sociais. $E$ isso significa que elas refletem sobre os perigos dessa separação e dessa transcendência.

Em uma coletânea de traduções, reunindo poemas de diferentes épocas e lugares, Augusto de Campos cunhou a expressão "poesia da recusa". Para ele, é possível tomar a recusa como postura poética. Como escreve Paul Valéry sobre Mallarmé: "o trabalho severo em literatura se manifesta e se opera por meio de recusas: pode-se dizer que ele é medido pelo número de recusas" (apud Campos 2006:15). Na coletânea organizada por Campos, encontram-se, de modo destacado, poemas do grupo de poetas russos - Aleksandr Blok, Ossip Mandelstam, Sierguei lessienin, Vladimir Maiakovski e Marina Tsvetaieva, entre outros - que, de alguma maneira, apoiaram a revolução de 1917 e, apesar disso, foram duramente perseguidos pelo Estado soviético, uma vez que sua criatividade parecia fugir do endurecimento político vigente. ${ }^{5}$ No final da década de 1970, Clastres uniu-se a pensadores como Claude Lefort e Cornelius Castoriadis, ambos ex-integrantes do grupo marxista "Socialismo e Barbárie", para fundar a

5 Campos vê na poesia de Marina Tsvetaieva uma "recusa ética". Fora da URSS, viveu a invasão da Tchecoslováquia pelos alemães. De volta à URSS em 1939, seu marido foi executado pelo governo stalinista, e sua filha presa. Ela acabou suicidando-se. Escreve Campos: "Sem encontrar um lugar, quer à direita, quer à esquerda, Tzevataieva recusou o mundo, como antecipara em seu poema, para ir ao encontro de seus parceiros de inconformidade: lessienin, Maiakovski. Após o degelo, a desestalinização, a glasnost, a história novamente os reunirá no mais alto patamar da poesia russa moderna" (2006, p. 149). 
revista Libre. Entre as propostas dos editores, estava a crítica ao totalitarismo soviético e o vislumbre de um marxismo mais humanista e libertário, bem como de novas alternativas para pensar a política e a democracia ( $A$ antropologia surgia então como elemento provocador, suscitando a imaginação de novas alternativas e apontando caminhos para a libertação). ${ }^{6}$

Para Clastres, mais especificamente, o socialismo, ao apoiar-se tão fortemente em uma burocracia estatal, nada mais faria do que reafirmar a lógica de qualquer Estado, aquela que opera pelo sacrifício de todas as diferenças em nome de uma unidade artificial, imposta pela força física e, inevitavelmente, pela Divisão entre dominantes e dominados. Segundo Clastres, todo Estado seria um órgão etnocida e, nesse sentido, assassino de possíveis. É preciso insistir que ele não toma o Estado como instituição com limites precisos. Com relação a esse etnocídio, Clastres (2004) entrevê a continuidade entre a ação dos Estados, do mercado em expansão (a globalização) e das empresas de normalização pedagógica ou conversão religiosa. Todas essas forças agiriam conjuntamente no sentido da homogeneização do mundo, da redução das diferenças a uma unidade, que é de fato a figura do poder coercitivo. A recusa libertária de Clastres poderia, enfim, encontrar-se com a recusa dos poetas russos traduzidos por Campos: seu compromisso é antes de tudo com a negação de um poder aniquilador dos possíveis e, assim, com a criação de multiplicidades (no seu caso, a multiplicidade das comunidades ameríndias, que dizem não ao Um).

O problema do Estado socialista, aponta Clastres, é que ele reincide na Divisão da sociedade. Acima da sociedade estaria posto um aparelho de Estado, operando por tributos e pela exigência de obediência. Crítico de um marxismo canônico, Clastres argumenta que o Estado não é resultado direto da desigualdade econômica, do trabalho alienado, é antes a desigualdade política que, para ele, obriga a desigualdade econômica. Para haver Divisão, é antes preciso que alguém seja obrigado a trabalhar para outrem, e isso seria, no limite, um ato voluntário. Clastres toma como apoio a interrogação de Etienne de la Boétie, em pleno século XVI: por que os homens aceitam obedecer a outro homem? Por que abrem mão de sua liberdade? Como escreve o autor do Discurso da servidão voluntária (1548), o ato de abrir mão da liberdade é um ato livre; no entanto, e paradoxalmente, uma vez perdida, a liberdade não poderia

6 Os textos de Lizot, Sahlins e H. Clastres publicados nos primeiros números da Libre cumpriam justamente essa missão de colocar em risco categorias como produção, trabalho, morte, guerra etc. 
ser recuperada, o que se perde seria de fato a própria natureza humana. Segundo Clastres, La Boétie escreve o Discurso no momento da Conquista, do encontro do Ocidente com os povos da América, sobretudo os "canibais" e "anárquicos" Tupi da costa brasileira. La Boétie buscaria na imagem do "mundo livre" indígena o escopo de sua crítica à sociedade monárquica e desigual vigente na França de sua época. Nas palavras de Clastres:

Mas como poderia esse jovem que, ao interrogar-se com tanta seriedade sobre a servidão voluntária, sonhava com a sociedade anterior ao mau encontro, como poderia ele não ficar impressionado com a imagem que, havia já longos anos, os viajantes traçavam desses 'povos inteiramente novos', selvagens americanos sem fé, sem rei, sem lei, povos em que o homem vive 'sem lei, sem imperador e cada um é senhor de si mesmo"? (2004, p.170)

Para Clastres, a recusa do Estado, da relação de poder é antes de tudo a vontade de liberdade, liberdade da qual abrimos mão. Estudar as sociedades indígenas seria uma maneira de compreender como elas "funcionam" de modo a impedir o Estado. Seria também um modo de questionamento sobre a natureza do Estado, da relação de poder. Como ele mesmo escreveu, questionar-se sobre a origem do Estado é ao mesmo tempo refletir sobre o seu fim, sobre a sua abolição. Contudo, Clastres jamais analisou a sociedade moderna, dizia-se etnólogo, estudioso das sociedades indígenas, sociedades contra o Estado. A pulsação maior de sua obra está em extrair da experiência dessas sociedades uma lição importante: o Estado, o poder coercitivo não é uma necessidade, não é o resultado do desenvolvimento social; seria possível, sim, viver fora do esquema do Estado, ainda que seus perigos - do poder de mando e obediência, da coerção, da divisão social - possam ser reconhecidos em toda parte. Nas palavras de Clastres, as sociedades primitivas são "sociedades da recusa do Estado, sociedades contra o Estado":

\footnotetext{
A ausência do Estado nas sociedades primitivas não é uma falta, não é porque elas estão na infância da humanidade e porque são incompletas, ou porque não são suficientemente grandes, ou porque não são adultas, maiores, é simplesmente porque elas recusam o Estado em sentido amplo, o Estado definido em sua figura mínima, que é a relação de poder. (2003, p. 237)
}

Clastres substitui o "sem Estado", próprio das interpretações dos antropólogos da primeira metade do século $\mathrm{XX}$, que tomam as sociedades primitivas sob o signo da ausência, pelo "contra o Estado", perfazendo assim uma espécie de "revolução copernicana". O Estado deixa de ser uma necessidade inerente a todo processo social. Diferentemente, ele se inscreve como uma possibilidade, que pode ser recusada ativamente. Nesse sentido, as sociedades indígenas re-conhecem a relação de poder, o 
ponto é que elas resolveram negar a sua irrupção. Ao longo de seus escritos, Clastres destaca dois mecanismos do "contra o Estado": o mecanismo da chefia esvaziada de poder e o mecanismo da guerra, que impede a unificação.

Clastres identifica uma "filosofia da chefia indígena" que não nega a constituição de um lugar para a relação de poder; o ponto é que esse lugar é esvaziado por um ato de recusa. Haveria sempre um chefe que "representa" o seu grupo, mas ele seria destituído de poder de mando e coerção. Seria tido, no mais, como um prisioneiro do grupo. Se o chefe indígena é muitas vezes agraciado com um privilégio que o destaca dos demais - a poligamia - isso faz com que ele adquira uma imensa dívida em relação ao seu grupo, dívida que deverá ser paga por meio de seus dotes mais fundamentais: a capacidade de apaziguar conflitos, a generosidade (distribuição de alimentos e riqueza) e, por fim, o dom da oratória. O chefe não pode, em suma, "bancar o chefe", tornando-se autoritário, pois se o fizer será destituído de seu lugar, será abandonado pelos seus. Mas se este chefe é mesmo destituído de poder, por que a insistência na instituição da chefia? Porque o grupo precisa do chefe, já que é ele quem o "apresenta" O ponto é que se ele não cumprir bem essa função, deverá ser destituído. A partir do encontro com o chefe guayaki Jivukugi, Clastres conclui para o mundo indígena:

\footnotetext{
O 'poder', encarnado pelos chefes, não é aí autoritário, não no sentido de que essas sociedades primitivas teriam ainda grandes progressos a fazer para chegar a se proporcionar uma verdadeira instituição política (quer dizer, semelhante à que se encontra em nossa própria civilização), mas no sentido de que essas sociedades 'selvagens' recusam, por um ato sociológico e portanto inconsciente, deixar seu poder tornar-se coercitivo. Os chefes são impedidos de utilizar sua função para fins pessoais; eles devem velar para que seus desígnios individuais não ultrapassem jamais os interesses da comunidade, estão a serviço do grupo, são seus instrumentos. Submetidos a seu controle permanente, os líderes não podem transgredir as normas que fundam e subtendem toda a vida social (1995, p. 69-70).
}

A sociedade contra o Estado é também uma "sociedade para a guerra", guerra compreendida como mecanismo de fragmentação social, garantia da autonomia das comunidades em detrimento de um processo de centralização do poder de decisão. Segundo Clastres, o ideal de vida social para os povos indígenas é aquele que se dá em comunidades pequenas e autônomas, fortemente fundadas nas relações de parentesco e afinidade. É, portanto, um ideal de dispersão, e não de centralização. Afinal, essas sociedades não deixam "nenhuma figura do Um destacar-se do corpo social para representá-la, para encarná-la como Unidade" (2004, p. 255). Os textos de Clastres sobre a guerra são fortemente inspirados por sua experiência etnográfica na década de 1970 entre os Yanomami, povo no qual a dinâmica dos conflitos está 
diretamente associada a um ideal de dispersão e aversão à centralização política. ${ }^{7}$ Clastres inverte o argumento de Hobbes, para quem a instituição do Estado se daria contra a guerra (de todos contra todos). Para Clastres, a guerra (não exatamente de todos contra todos, pois é sempre necessário distinguir inimigos e aliados) pode ser, ao contrário, contra o Estado. Ele distingue a guerra primitiva da guerra de conquista: diferentemente desta, interessada na expansão territorial e na subordinação de outras populações, aquela tem por objetivo a garantia da liberdade, por isso sua violência é localizada, jamais ocorrendo em escala ampliada. O famoso exemplo da guerra tupinambá, descrita no século XVI, atesta este ponto: as expedições guerreiras tinham por objetivo não a rendição de todo um grupo, ou a apreensão de escravos, mas a obtenção de um ou poucos cativos para serem "domesticados" e então devorados. Como concluirá mais tarde Eduardo Viveiros de Castro (1986), a guerra tupi teria como finalidade a vingança, a relação com o inimigo, e essa vingança é também a recusa da identificação consigo próprio.

A concepção de guerra como mecanismo contra a unificação e a favor das autonomias locais foi especialmente discutida por Gilles Deleuze e Félix Guattari no “Tratado de nomadologia: a máquina de guerra”, nono platô dos Mil Platôs (Capitalismo e Esquizofrenia II). Deleuze e Guattari sofisticam a proposição de Clastres, que parecia restrita às ditas "sociedades primitivas", tornando a máquina de guerra uma "máquina abstrata" - uma força ativa - e também um conceito capaz de povoar o novo universo da filosofia. Como escreve Viveiros de Castro (2011), os autores de Mil Platôs transformam a "sociedade contra o Estado" em um "conceito universal", algo que pode ser buscado em nós mesmos. No referido platô, os autores prestam uma "homenagem" a Clastres, colocando-lhe, contudo, uma questão: que Estado é este que surge de um só golpe transformando de maneira irreversível as sociedades primitivas em sociedades divididas? Em linhas muito gerais, Deleuze e Guattari argumentam

\footnotetext{
7 Clastres (2004) escrevia que os Yanomami eram a "última sociedade primitiva". Com efeito, ele os conhecia num momento em que parte de sua população ainda não havia sofrido os impactos mais terríveis das epidemias e dos conflitos com os garimpeiros. Para uma história desses impactos e de uma outra recusa, agora formulada em termos de xamanismo, ver o livro fascinante escrito em co-autoria por Davi Kopenawa e Bruce Albert (2010), que é de fato o relato da vida deste primeiro autor, habitante da serra do Demini, Roraima.
} 
que há algo de evolucionista na ideia de que existe uma diferença de natureza entre sociedades "contra" e sociedade "com" Estado. Para eles, é preciso pensar em termos de "coexistências" (entre "regimes de signos" ou "processos maquínicos") e "causalidades reversas" (contrárias à ideia de uma flecha do tempo unívoca) e, para tanto, valeria pensar a "sociedade contra o Estado" não em termos de um "tipo" de formação social, mas sim como um conjunto de forças e vetores que podem existir de maneira dominante ou recessiva em todas as formações sociais.

Para Deleuze e Guattari, o "primitivo" ou "selvagem" não poderia ser um tipo de sociedade, mas um "processo maquínico", que pode agir sobre o nosso mundo, ainda que de maneira menos evidente. Em vez de "sociedade contra o Estado", eles fazem referência a "mecanismos coletivos de conjuração", mecanismos de recusa do Estado, ou melhor, da forma-Estado, uma "segmentaridade dura", que traduz processos de unificação, de dissolução das diferenças, de produção de espaços hegemônicos. Note-se que a conjuração, a recusa, implica, para os autores, uma ideia de antecipação, isto é, para recusar algo é preciso antes imaginá-lo, prefigurá-lo. Nesse sentido, resistir é conhecer - quiçá mimetizar - o inimigo.

Deleuze e Guattari fazem render a máquina de guerra clastriana, ultrapassando o quadro sociopolítico traçado por Clastres. Para eles, os mecanismos inerentes aos processos políticos também o são quando se trata do pensamento em sentido mais amplo. É nesse sentido que um pensamento nômade ou guerreiro contrapõe-se a um pensamento estatal, régio, ao mesmo tempo em que pode coexistir com ele. Para Deleuze e Guattari, seria mesmo possível subtrair do (nosso) pensamento um modelo de Estado, traçando "linhas de fuga". Como escrevem em Mil Platôs, a essência da máquina de guerra - recusa do Estado em seu sentido mais abstrato, mas também de uma axiomática mundial expressa pelos Estados (a tal globalização do mercado e do capital) - é "o traçado de uma linha de fuga criadora, composição de um espaço liso" (1997, p. 109). Uma linha de fuga é aquilo capaz de dissolver esquemas hegemônicos, de redirecionar os fluxos de maneira imprevisível, isto é, criadora. Deleuze recupera essa ideia de linha de fuga em seus Diálogos com Claire Parnet:

Fugir não é renunciar às ações, nada mais ativo do que uma fuga. É o contrário do imaginário. É também fazer fugir, não necessariamente os outros, mas fazer alguma coisa fugir, fazer um sistema vazar como se fura um cano (1998, p. 49).

Ou ainda: 
O grande erro, o único erro, seria acreditar que uma linha de fuga consiste em fugir da vida; a fuga para o imaginário ou para a arte. Fugir, porém, ao contrário, é produzir algo real, criar vida, encontrar uma arma (idem, p. 62).

Linhas de fuga dizem respeito a processos de criação - criação de grupos de pessoas (no caso da política), criação de conceitos (no caso da filosofia), mas também criação artística. No caso da citação acima, Deleuze faz referência à literatura, mais especificamente a literatura anglo-americana - aqui podemos traçar um paralelo com a "poesia da recusa" na qual se engaja Augusto de Campos. Para Deleuze, o processo criativo é por definição um "devir-outro", um "devir-minoritário". Clastres, antropólogo e filósofo, que aspira a uma filosofia política por meio do diálogo com o pensamento dos povos que estuda, é também um escritor. Veja-se o cuidado e o interesse que ele alimenta em relação à linguagem de seus textos: linguagem ensaística que recupera um certo gênero retórico que antecede o estilo discursivo da filosofia moderna, ${ }^{8}$ mas sobretudo, a linguagem que se oferece como antídoto da coerção, como se pode observar na fala dos chefes indígenas, que não enunciam mandos, mas sim a celebração da vida comum, que é a própria celebração da linguagem não como signo, mas como valor. Ou nos cantos de seus xamãs, que efetuam um devir não humano, divino ou animal. Voltando à meditação de Deleuze sobre o processo criativo implicado na escrita literária: poderíamos arriscar e dizer que, assim como nos cantos xamânicos indígenas, aos quais tomam emprestado a palavra dos outros (espíritos, deuses, inimigos, animais etc.), ${ }^{9}$ "escrever [outro modo de dispor da linguagem] é traçar linhas de fuga, que não são imaginárias, que se é forçado a seguir, porque a escritura nos engaja nelas, na realidade, nos embarca nela. Escrever é tornar-se [é devir], mas não é de modo algum tornar-se escritor. É tornar-se outra coisa" (idem, p. 56).

Mas Deleuze nos lembra que toda linha de fuga - assim como toda máquina de guerra - é tão libertária quanto perigosa: é tanto capaz de desfazer um esquema como conduzir a uma linha de abolição (autodestruição, derrotismo, niilismo). Ele se pergunta, ainda em vista da literatura: "como fazer para que a linha de fuga não se confunda com um puro e simples movimento de autodestruição?" (Idem, p. 54). A conversão da linha de fuga em linha de abolição implica o divórcio da recusa com a criação, a transformação de uma recusa ativa em uma recusa reativa, autofágica.

8 Goldman (2011), por sua vez, sugere que Clastres recupera o estilo aforismático de um filósofo como Nietzsche. 9 Ver, nesse sentido, Viveiros de Castro (1986) e Cesarino (2013). 
Escrever, criar é, portanto, devir-outro. E toda recusa seria, antes de tudo, a recusa da identidade, da univocidade. Esse ponto nos permite traçar novamente o paralelo entre o devir na literatura anglo-americana e aquele que salta dos cantos e pensamentos xamânicos de diferentes povos indígenas. São de imenso valor os escritos de Clastres - a um só tempo curtos, precisos e poéticos - sobre a metafísica dos povos guarani, com quem ele conviveu, tanto nos bosques paraguaios como nos arredores de uma metrópole como São Paulo (onde, aliás, lecionou em 1974). Clastres encontrou nos mitos, nos cantos e nas exegeses dos xamãs mbyá guarani toda uma metafísica singular, capaz de desterritorializar certezas da filosofia ocidental. (Com isso, ele antecipava a grande "revolução metafísica" proposta pela antropologia de Eduardo Viveiros de Castro, ele também um estudioso de povos de língua tupi-guarani.) Clastres encontra entre os Guarani Mbyá o que Deleuze e Guattari chamariam de uma "máquina de guerra do pensamento": no caso, uma metafísica que recusa a identidade e o princípio da não contradição (contrapondo-se à metafísica do Ser arquitetada na Grécia Antiga na contracorrente de muitos pensadores pré-socráticos) e impele ao movimento, efetuando uma crítica da condição humana em nome da possibilidade de um devir divino, alcançável na busca de uma terra sem mal.

Os xamãs mbyá, a quem poderíamos chamar sábios ou mesmo filósofos, dizem que os homens habitam uma "terra imperfeita" - e que teria se tornado ainda mais, com a chegada dos brancos (Juruá). Para tanto, seria preciso buscar uma terra sem mal, habitadas pelos seres divinos, com quem se teria perdido a comunicação num tempo mitológico. Essa busca, também a busca por um estado de "perfeição" ou "completude" (aguyje), poderia ser dada no espaço - por meio de migrações e busca de novos territórios - ou no ritual - por meio de uma ética corporal (fazer o corpo leve pela dança e pelo canto). A imperfeição da terra em que os homens habitam seria dada, segundo os xamãs guarani, pelo fato de que "as coisas em sua totalidade são Uma," o Um se revelando como figura do Mal. Clastres escreve:

Desgraça da existência humana, imperfeição do mundo, unidade ao mesmo tempo que fenda inscrita no âmago das coisas que compõem o mundo: eis o que recusam os índios Guarani, e eis o que os levou em todos os tempos a procurar outro espaço, para lá conhecer a felicidade de uma existência curada de sua ferida essencial, de uma existência desdobrada sobre um horizonte liberto do Um. (2003:189)

Em seguida, pergunta-se pelo que poderia ser esse "não-Um" desejado pelos Guarani. Sugere, então, que a resposta desses índios afasta-se da resposta dos 
antigos gregos: "Mas se se encontra [entre estes] a insurreição ativa contra o Império do Um, não é todavia o Múltiplo que é afirmado pelos Guarani, pois eles não descobrem o Bem, o Perfeito na dissolução mecânica do Um" (idem, ibidem).

Para os Guarani, sugere Clastres, o Um seria toda coisa corruptível, tudo que se mantém sob o signo do finito. A terra imperfeita seria o reino do incompleto, espaço do finito, campo de aplicação rigorosa do princípio de identidade, que alega que homens não são e nem podem ser deuses. Mas os Guarani preferem dizer que são homens e, ao mesmo tempo, deuses. A linguagem que separa homens e deuses seria uma linguagem enganadora, pois está subordinada às formas do Um e da identidade. Na região do não-Um, a terra sem mal, todos são homens e deuses, portanto o Dois sobrepõe-se ao Um. Clastres resume aqui o que haveria de mais central nessa metafísica

O Mal é o Um. O Bem não é o Múltiplo, mas o Dois, ao mesmo tempo o um e seu outro, o dois que designa verdadeiramente os seres completos. Yvy marã-ey [terra sem mal], destinação dos últimos homens, não abriga mais deuses: somente iguais, deuses-homens, homens-deuses, tais que nenhum dentre eles se diz segundo o Um (idem, p.191).

A terra sem mal seria, pois, o lugar do não-Um, do devir, e a ela se poderia chegar seja pela migração no espaço, seja pelas atividades rituais, fortemente ancoradas na palavra dos cantos, que abusam de metáforas para se comunicar com os deuses. Aqui nos deparamos, contudo, com o desalento de muitos povos guarani, como os Guarani Kaiowá, com quem abrimos este ensaio. A eles têm sido privada a experiência mais importante, que é a da mobilidade, da circulação num espaço aberto devido a um processo de expropriação da terra e de confinamento. Mas a resistência dos Guarani, lembra Clastres, antes de ser política e territorial no sentindo mais moderno desses termos é metafísica, pois seu território e sua política são, antes de tudo, "existenciais", para lembrar uma expressão cara a Félix Guattari. Os Guarani resistem ao mundo dos juruá para poderem viver a sua experiência de devir, convertem esse devir em arma política e não o contrário. Pensam-se, assim, como os "últimos homens", os últimos a poderem se comunicar com os deuses, a recusar a terra má e imperfeita. ${ }^{10}$

10 O tema da busca da terra sem mal, que encerra todo um profetismo, e do "desalento guarani" diante da impossibilidade da desejada mobilidade foi tratado de maneira magistral por Hélène Clastres (1975). 
Recusa do Um. Elogio do Dois. O tema refletido na metafísica guarani - que se revela em mitos e cantos xamânicos, mas também em exegeses nas quais esses sábios indígenas se aproximam de um discurso propriamente filosófico - ecoa em outros cantos das Américas. Nesse momento, seria preciso passar dos escritos singelos e poéticos de Clastres sobre os Guarani para a grandeza das Mitológicas de Claude Lévi-Strauss, que culminam com uma reflexão sobre o pensamento dualista dos ameríndios. Faço referência à última das "pequenas Mitológicas", História de Lince, e, mais especificamente, a seu epílogo, "A ideologia bipartida dos ameríndios". Ao longo do livro, Lévi-Strauss recupera o mito tupi-guarani dos "gêmeos desiguais", mito cuja versão guarani é reproduzida e discutida por Clastres em A fala sagrada. Em linhas muito gerais, esse mito conta a história de um par de gêmeos, humanos primordiais que modelam o mundo tal como o conhecemos. Em muitas versões, são filhos da mesma mulher, porém com pais diferentes, um deles, o grande demiurgo que abandona a terra, o outro, um personagem "enganador", muitas vezes encarnado na figura do Gambá. Em muitas versões, aparecem como Sol e Lua, o primeiro caracterizado pela sua constância, o segundo, pelo seu caráter desastrado. A mãe dos gêmeos é devorada pelas onças ancestrais, que resolvem então criar as crianças. Descobrindo a causa da morte da mãe, estes planejam vingança, que culmina na transformação das onças ancestrais (que eram "gente") em animais propriamente ditos. Daí em diante, os gêmeos seguem em busca do pai-demiurgo e vão criando tudo o que há no cosmos. ${ }^{11}$

Apenas essa paráfrase bastaria para nos darmos conta de que essa mitologia veicula uma filosofia que afirma que tudo no mundo foi feito a partir de um princípio dual, e esse dualismo carrega em si uma certa dose de assimetria, ou melhor, instabilidade. Nega-se aos gêmeos a perfeita identidade. Em vez disso, eles aparecem como desiguais, antitéticos, porém complementares. Em suma, essa mitologia encerraria em si mesma uma espécie de elogio da diferença, e recusa da identidade. Lévi-Strauss ressalta a recorrência desse mesmo tema mitológico ao longo de todo o continente americano, passando do Brasil Central à Amazônia, e desta ao noroeste da América do norte. Escreve Lévi-Strauss:

Companheiros, gêmeos ou não, desigualmente dotados física ou moralmente, vivem as mesmas aventuras e cooperam entre si. O mais inteligente ou mais forte conserta os erros ou imperícias do outro, e até o ressuscita, se ele morrer vítima de sua própria incapacidade: assim, Pud e Pudleré dos Krahô, Kéri e Kamé dos Bakairi, Méri e Ari dos Bororo, Dyoi e Epi dos Tukuna, Makunaíma e Pia dos Karib etc. (1993, p.205)

11 Para uma análise desse mito a partir de versões kaiowá, ver Pimentel (2008). 
Ao final de História de Lince, Lévi-Strauss reconhece a proliferação de mitologias que trazem a figura dos gêmeos, em outras regiões que não as Américas, e se pergunta se estamos, enfim, diante de um traço universal ou de uma particularidade ameríndia. Com efeito, a gemelaridade está em toda parte. No entanto, Lévi-Strauss distingue duas "fórmulas": de um lado, aquela que toma a figura de gêmeos de sexo oposto como origem da humanidade por meio de um ato incestuoso (ele faz referência à mitologia do Rigveda indiano); de outro, aquela que toma a figura de gêmeos de mesmo sexo que se revelam pelo seu caráter antitético. No que diz respeito a essa última "fórmula", Lévi-Strauss distingue ainda duas "soluções", comparando o mito grego de Castor e Polux aos mitos ameríndios sobre a gemelaridade. O ponto de partida é muito semelhante: Castor e Polux são gêmeos, filhos de pais diferentes: o primeiro é filho de Tindaro de Esparta (um mortal), o segundo, de Zeus (divindade suprema que se apresenta à Leda, uma mortal, sob a forma de um cisne). Castor morre, causando desalento a Polux. Diferentemente dos mitos tupi, em que o irmão desastrado morre várias vezes e é ressuscitado pelo outro irmão, e esses ciclos tecem a epopeia criadora dos gêmeos que seguem em busca do pai-demiurgo, no mito grego Polux implora ao pai Zeus que ressuscite o irmão. O resultado disso é que Polux passa a "dividir" a imortalidade com Castor, ambos permanecendo meio ano no Hades, meio ano no Olimpo. Como aponta Lévi-Strauss, essa divisão simétrica da imortalidade os torna um par de idênticos, ao passo que no caso ameríndio o que temos é uma incessante dualidade, um “dualismo em perpétuo desequilíbrio", altamente criativo e criador. A diferença dos gêmeos ameríndios, tal como expressa na mitologia, seria, segundo Lévi-Strauss, a mola mestra tanto da cosmologia como da sociologia desses povos: nada pode ser Um, tudo é Dois. ${ }^{12}$

Se a mitologia do "velho mundo" busca na figura dos gêmeos de mesmo sexo uma solução, seja de igualdade (Castor e Polux), seja de extrema rivalidade (Rômulo e Remo, Caim e Abel); a mitologia do "novo mundo" estaria pautada em uma recusa da identidade. A identidade seria aí um estado provisório, que não pode durar. Reencontramos aí com a filosofia ou metafísica da mitologia e suas exegeses apontadas por Clastres: o Dois emerge como problema alternativo à oposição grega entre o Um e o Múltiplo. Os ameríndios buscariam nesse "dualismo em perpétuo desequilíbrio" uma

12 Uma discussão do argumento de Lévi-Strauss sobre esse "dualismo em perpétuo desequilíbrio", bem como da possibilidade de extrair da mitologia filosofias políticas, pode ser encontrada em Perrone-Moisés (2011). 
lição para o mundo, algo que não estaria desvinculado de uma recusa ativa, recusa da identidade, que é também a da unificação, da redução ao Um, supressão das diferenças.

Muitos antropólogos se ocuparam do problema do dualismo ameríndio, e isso ocorreu pelo simples fato de que se trata aqui de um problema propriamente ameríndio, problema que invade, como já ressaltado, tanto a cosmologia, como a sociologia e mesmo a política desses povos. David Maybury-Lewis (1989), estudioso dos povos jê e bororo do Brasil Central, povos conhecidos por proliferar em suas aldeias pares de metades sociológicas e cerimoniais, escreveu certa vez que o dualismo como ideologia empresta-se enquanto instrumento eficaz de controlar a entropia que advém das situações de intenso contato com o mundo dos brancos. Em poucas palavras, para ele, o dualismo pode ser tomado como resistência. Maybury-Lewis cita o exemplo dos povos Xavante e Kayapó, ambos de língua jê, que não cessam de criar novos pares de metades de caráter sociológico e político para lidar com desafios postos pela presença dos brancos. Com suas metades, eles reduziriam a desordem a princípios antitéticos, porém complementares, como o fizeram no tempo do mito os gêmeos criadores, da mesma maneira em que evitariam uma excessiva polarização, que poderia culminar em certa forma de dominação.

O dualismo é, portanto, peça central da recusa existencial e ativa a que tenho me referido neste ensaio. Não por acaso, ele se empresta como forma primordial de um espetáculo como Recusa. Como na mitologia, vemos pares se desdobrar incessantemente: os dois atores são também os dois personagens mitológicos que criam o cosmos ameríndio, e que se replicam na história: dois índios Piripkura, os gêmeos criadores dos Krahô, Pud e Pudleré, outro par mitológico de heróis antitéticos (desta vez, contados pelos índios do lavrado de Roraima), Piá e seu irmão "desastrado", mais conhecido como Macunaíma, "herói sem nenhum caráter", como o chamaria Mário de Andrade. Recusa termina com outra figura incontestável do dualismo ameríndio: o par de dançarinos e cantores mascarados karajá que, juntos e apenas juntos, personificam um espírito ijasò ou aruanã. Os ijasò ou aruanã são os ancestrais dos humanos, vivem no mundo subaquático e, graças aos xamãs, podem ser trazidos à terra e alimentados, fornecendo poderes criativos e procriativos, sem os quais a vida social se tornaria inviável. Os ijasò ou aruanã são responsáveis, portanto, por vários níveis de criação, da criação de pessoas à criação de conhecimentos e coisas; e para que eles atuem é preciso cantar e dançar, algo que só se faz possível com um par, jamais com uma só pessoa. 
Assim dizem e fazem os Karajá (Iny) da ilha do Bananal. Assim parece se desdobrar uma recusa propriamente ameríndia, recusa da identidade que ganha, como tão bem sugeriram Lévi-Strauss e Clastres, versões metafísicas, estéticas, éticas e (socio) políticas. Recusa, lição ameríndia, que pode ser reencontrada em nós mesmos, como tão bem sugeriram Deleuze e Guattari. Pois uma recusa ativa é sempre um ato de resistência, é sempre um ato de criação. Recusa é, assim, a prova de que essas tantas recusas podem ainda emocionar o espectador de um mundo de tantas concessões como é o "nosso". Recusa faz com que experimentemos em nós mesmos a recusa dos outros, unindo assim uma proposta estética a um compromisso ético e político.

\section{Referências bibliográficas}

CAMPOS, Augusto. A poesia da recusa. São Paulo: Perspectiva, 2006.

CASTRO, Eduardo Viveiros de. Araweté, os deuses canibais. Rio de Janeiro: Zahar/Anpocs, 1986.

O intempestivo, ainda (Posfácio). In: CLASTRES, Pierre. Arqueologia da violência: investigações de antropologia política. São Paulo: Cosac Naify, [1980] 2011.

CESARINO, Pedro de N. "Apresentação". In: Cesarino, P. (org.). Quando a terra deixou de falar: cantos da mitologia marubo. São Paulo: Ed. 34, 2013.

CLASTRES, Hélène. La terre sans mal: le prophétisme tupi. Paris: Seuil, 1975.

CLASTRES, Pierre. A fala sagrada. Campinas: Papirus, 1990.

. Crônica dos índios Guayaki: o que sabem os Aché, caçadores nômades do Paraguai. São Paulo: Ed. 34, [1972]1995.

A sociedade contra o Estado: investigações de antropologia política. São Paulo: Cosac Naify, [1974]2003.

Arqueologia da violência: investigações de antropologia política. São Paulo: Cosac Naify, [1980]2004.

DELEUZE, Gilles; GUATTARI, Félix. Mil platôs: capitalismo e esquizofrenia II. Volume 5. São Paulo: Ed. 34, [1980]1997.

DELEUZE, Gilles; PARNET, Claire. Diálogos. São Paulo: Escuta, 1998.

GOLDMAN, Marcio. Pierre Clastres ou uma antropologia contra o Estado. Revista de Antropologia, vol. 54, n. 2, 2011.

GOW, Peter. Me deixa em paz: um relato preliminar sobre o isolamento voluntário dos Mashco. Revista de Antropologia, vol. 54, n. 1, 2011.

KOPENAWA, Davi; ALBERT, Bruce. La chute du ciel: paroles d'un chaman yanomami. Paris: Plon, 2010.

BOÉTIE, Etienne de La. Discurso da servidão voluntária. São Paulo: Brasiliense, [1548]1982.

LÉVI-STRAUSS, Claude. História de lince. São Paulo: Companhia das Letras, [1991]1993.

MAYBURY-LEWIS, David. "The quest for harmony" \& "Social theory and social practice: binary systems in Central Brazil". In: MAYBURY-LEWIS, D.; ALMAGOR, U. (Eds.). The attraction of the opposites: thought and society in dualistic mode. Michigan: University of Michigan Press, 1989. 
PERRONE-MOISÉS, Beatriz. Bons chefes, maus chefes, chefões: elementos de filosofia política ameríndia. Revista de Antropologia, vol. 54, n. 2, 2011.

PIMENTEL, Spensy. Kuarahy e Jasy em busca da origem: um olhar sobre o mito dos gêmeos entre os Guarani-Kaiowa e as relações de contato. Anais da $26^{a}$ Reunião da Associação Brasileira de Antropologia, 1998. http://www.abant.org.br/conteudo/ANAIS/CD_Virtual_26_ RBA/grupos_de_trabalho/trabalhos/GT\%2026/spensy\%20kmitta\%20pimentel.pdf

Decretem nossa morte coletiva e nos enterrem todos aqui... In: http://desinformemonos. org/2012/10/decretem-nossa-morte-coletiva-e-nos-enterrem-todos-aqui-dizem-guaranikaiowa-da-comunidade-de-pyeblito-kue/
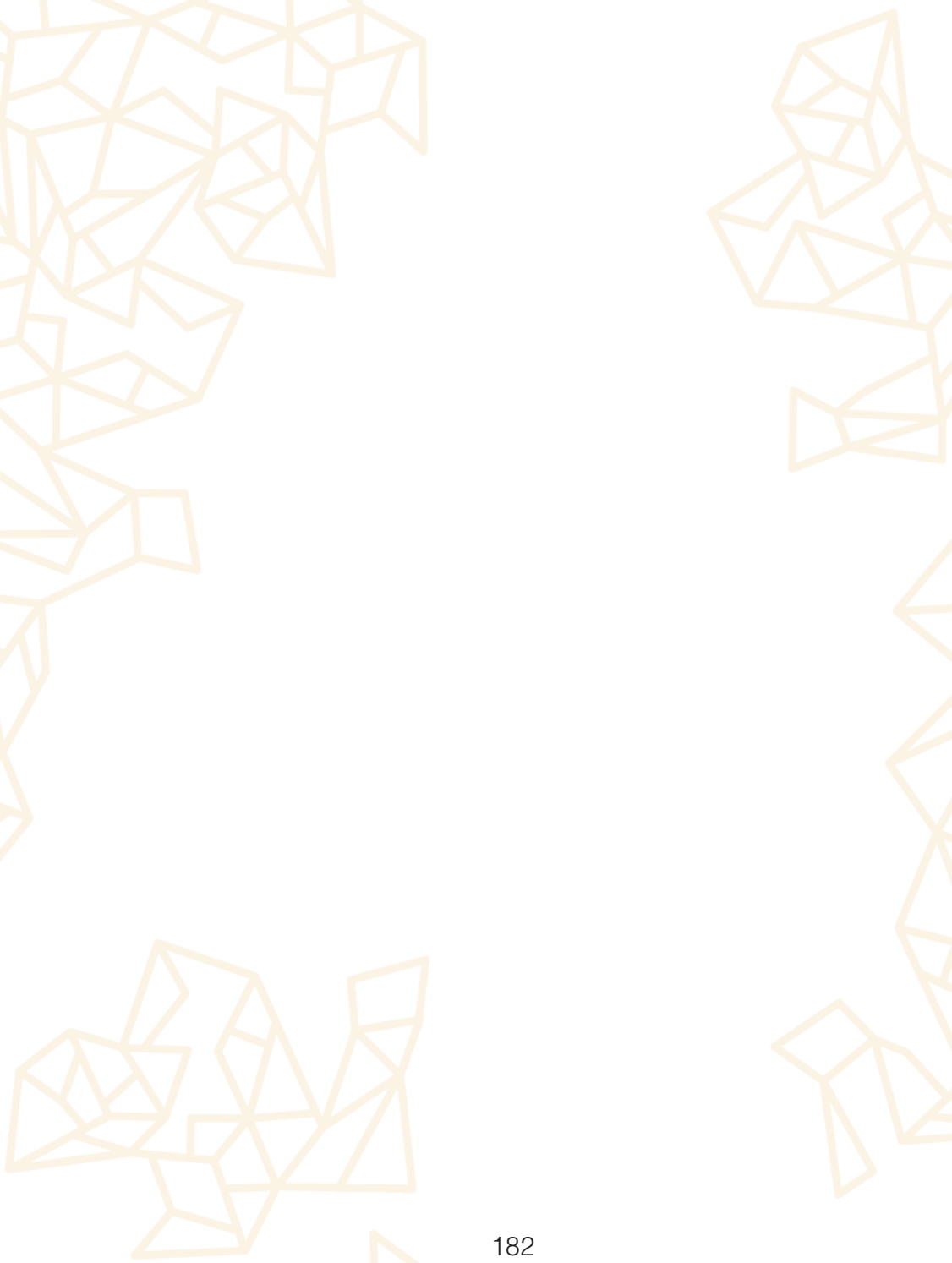